\title{
The Discourse of Tribalism in Botswana's 2019 General Elections
}

\author{
Christian John Makgala \\ ORCID iD: https://orcid.org/0000-0001-5984-5153
}

\author{
Andy Chebanne \\ ORCID iD: https://orcid.org/0000-0001-5393-1771
}

Boga Thura Manatsha

ORCID iD: https://orcid.org/0000-0001-5573-7796

Leonard L. Sesa

ORCID iD: https://orcid.org/0000-0002-6406-5378

\begin{abstract}
Botswana's much touted peaceful Presidential succession experienced uncertainty after the transition on 1 April 2019 as a result of former President Ian Khama's public fallout with his 'handpicked' successor, President Mokgweetsi Masisi. Khama spearheaded a robust campaign to dislodge Masisi and the long-time ruling Botswana Democratic Party (BDP) from power. $\mathrm{He}$ actively assisted in the formation of a new political party, the Botswana Patriotic Front (BPF). Khama also mobilised the country's most populous Central District, the Bangwato tribal territory, of which he is kgosi (paramount chief), for the hotly contested 2019 general elections. Two perspectives emerged on Khama's approach, which was labelled loosely as 'tribalism'. One school of thought was that the Westernised and bi-racial Khama was not socialised sufficiently into Tswana culture and tribal life to be a tribalist. Therefore, he was said to be using cunningly a colonial-style strategy of divideand-rule to achieve his agenda. The second school of thought opined that Khama was a 'shameless tribalist' hell-bent on stoking 'tribalism' among the 'Bangwato' in order to bring Masisi's government to its knees. This article,
\end{abstract}


however, observes that Khama's approach was not entirely new in Botswana's politics, but only bigger in scale, and instigated by a paramount chief and former President. Since Botswana's independence in 1966, 'tribalism' has invariably been used by individual politicians as a short-term political strategy, but hardly paid dividends. Therefore, Khama's case in 2019 was no exception despite enlisting the support of his influential South African acquaintances and business moguls.

Keywords: Botswana, 2019 elections, tribalism/ethnicity, chieftainship, political parties.

\section{Introduction}

In sub-Saharan Africa, the horrors of 'tribalism' and 'ethnicity' and how both undermine nation-building, often resulting in civil strife, political violence and civil wars, are well documented (Adeyanju 2020; Daley 2006). Therefore, there is no need to recount the literature. Nonetheless, few examples include Nigeria, Kenya, Rwanda, Burundi and South Sudan (Nasong'o 2015). In addition to the national elections wherein campaigns follow virulent tribal and ethnic lines in these countries, there had also been cataclysmic ethnic conflicts as happened in Rwanda in 1994. Variously defined, ethnic conflict is an 'organized large-scale violent conflict among ethnic groups of which at least one has not achieved statehood or is not in possession of the state apparatus' (Angstrom 2000:25). Tribalism, which we define in the next section, is a serious curse in Africa too, perhaps after corruption and authoritarianism, even though the three sometimes run concurrently. Tribalism and ethnicity in Africa have elicited intense debate (Adeyanju 2020; Ake 1993; Daley 2006; Mafeje 1971; Venkatasawmy 2015).

For instance, the popular Johannesburg-based Big Brother television reality show, which started in 2003 and ran for a few years with competitors from about ten different sub-Saharan African countries, was, in some quarters, seen as a 'pan-African' initiative capable of uniting Africans at a continental level and in their respective countries. However, one Kenyan housemate's experience in 2007 demonstrates the contrary. He cited tribalism as a grave problem and sombrely complained that 'My home coming was far from happy. Instead of being viewed as a Kenyan, throughout my time in the show, some 
of my compatriots saw me as part of a Luo [tribal] project that had gone to the house for political reasons. I found this very disturbing [...] Just as crooked was the media which ended up spreading words of hate along tribal lines' (Motlhabani 2013:104). Since 1963, Kenya has always witnessed explosive 'ethnic tensions', especially between the Kikuyu and the Luo, resulting in political violence and killings (Opondo 2014). In late December 2007, for instance, Kenya was plunged into deadly political violence, along ethnic lines, following the disputed Presidential elections, which Raila Odinga, a Luo, and Mwai Kibaki, a Kikuyu, claimed to have won. The Kenyan Election Commission declared Kibaki the winner, whereas the national and international election observers doubted the integrity of these elections (Cheeseman 2008; Opondo 2014).

By the sub-Saharan African standards, Botswana's nation-building exercise has been successful, making tribalism and ethnicity, as disruptive forces, ineffectual because of the democratic culture, tolerance, multi-culturalism and multi-layered ethnic identities (Mulimbi 2017). Werbner (2004) argues that despite some strong feelings by the so-called minorities against the so-called majority ethnic groups in Botswana, over some legitimate concerns, the situation is far from reaching the 1994 Rwandan genocide. He contends that the elites in Botswana, from across ethnic groups, work hand in hand to pursue business interests (Werbner 2004). Thus, these elites cannot jeopardise such lucrative business interests, hence he calls one of the group, the Bakalanga elites, 'reasonable radicals' (Werbner 2004). It has been observed, in some quarters, that 'Botswana is arguably Africa's most tribally-integrated country' (Sunday Standard 22-28 December 2019). Ethnic and tribal tolerance and political stability greatly contributed to Botswana's economic development leading to some academics labeling the country 'An African Miracle' (Samatar 1999) and 'An African Success Story' (Acemoglu, Johnson and Robinson 2002). Some critics, however, see Botswana as an 'African Mirage' (Magang 2015) because of the inequalities, rife unemployment and endemic poverty amidst plenty (Mogalakwe \& Nyamnjoh 2017). Nonetheless, the country's successive Presidents have been pretty-aware of the dangers inherent in tribalism and ethnicity. For instance, the second President, Sir Ketumile Masire (1980-1998), described tribalism as a harnessed tiger, which, if it escapes from its leash, can cause untold destruction and horror (Masire 2006).

This article was produced under the purview of a larger 'sub-PanAfrican' project that seeks to address how the impacts of decolonisation, deculturalisation, neo-colonialism, globalisation and xenophobia can be 
reversed. The initiative is in line with the ideals of the New Partnership for African Development and African Renaissance pioneered by former President Thabo Mbeki of South Africa at the turn of the new millennium. Basically, the article examines a legacy in public life and the state in Botswana. ${ }^{1}$ Quite briefly, we first explain the concepts of tribalism and ethnicity in the context of sub-Saharan Africa. This is followed by a background on the discourse of tribalism in Botswana from 1975 to 2019. We then move on to focus on Ian Khama's political history, followed by his 'deculturalisation' and presidency.

We also examine Khama's 'fallout' with his 'chosen' successor, President Masisi. This 'fallout' worsened during the build-up to the historic BDP's 'elective' congress in Kang, in which accusations and counteraccusations of tribalism and scheming were traded by both sides. The deteriorating relations between Khama and Masisi saw the latter influencing the formation of the Botswana Patriotic Front (BPF), which some dismissed as blatant tribalism. The public debate, which ensued out of this so-called tribalism, is central to this article. It ends by examining Khama's support from some South African political and business elite.

\section{Tribalism, Ethnicity and Politics}

Scholars, from various disciplines, have broadly written on the relations between 'ethnicity', 'tribalism' and politics in postcolonial Africa (see Adeyanju 2020; Ake 1993; Berman 2010; Calhoun 1993; Daley 2006; Hale 2004; Mafeje 1971; Opondo 2014). Therefore, our intention is not to reinvent the wheel. It suffices, however, to note that there is a consensus that tribalism and ethnicity are 'predominantly problematic in Africa' (Ake 1993:1). Studies also concur that these concepts are a colonial creation. Before colonial intrusion, for instance, Africans lived in clans, extended families, chiefdoms and kingdoms, and the word 'tribe' did not exist in their languages (Mafeje 1971:254). Therefore, colonialism and colonisation brought about radical changes such that 'political ethnicities' and 'tribes' were wittingly and unwittingly created, and sometimes with calamitous consequences as seen in Rwanda and Burundi, among other African countries (Daley 2006; Carney

1 We are grateful to Professor Richard Werbner for this idea (email communication with Richard Werbner, 16 January 2020). 
2012; Opondo 2014). Colonial policies, such as the British indirect rule policy, 'provided the material as well as the ideological base of what is now called "tribalism" (Mafeje 1971:254). Mafeje, critical of the colonial creation of 'tribes' and 'ethnicities', argue that 'if tribalism is thought of as peculiarly African, then the ideology itself is particularly European in origin' (1971:253). Before the Europeans' arrival, Africans lived in their own way and did not regard themselves as 'tribes' or 'ethnic groups'. Mainly for this reason, some scholars conclude that 'ethnicity is not suprahistorical and quasi-natural membership in a group, but rather a social ideology constructed under specific historical-political circumstances' (Lentz 1995:306). For conceptual clarity, we define the two concepts.

According to Albeely, Mahmoud and Yahaya (2018:32), 'tribalism signifies a sense of identity for the tribe members that surpasses the national identity, and [is] often accompanied by feelings of superiority over members of other tribes'. Such feelings may lead to intense contestations, ethnic rivalry and conflicts, especially in relation to the attainment of political office or access to and ownership of national resources and their distribution (Opondo 2014; Venkatasawmy 2015). Simply put, a tribe refers 'to a social entity that carries and reinforces the values and social bonds between the group members (i.e. the tribe) and serves their benefits and protection' (Albeely, Mahmoud \& Yahaya 2018:31). On the other hand, ethnicity 'refers to the character of social relationship existing between members of two or more ethnic groups in a plural society. It shows how they relate because of ethnic sentiments and consciousness between them' (Albeely, Mahmoud \& Yahaya 2018:31). In some instances, however, and as witnessed elsewhere in Africa and beyond, tribalism and ethnicity often result in tribal bigotry and ethnic conflicts. Hettne (1993:126) rightly contends that 'the type of identity usually referred to as 'ethnic' can be manipulated for political purposes and thereby transformed'.

During the colonial period, colonial administrators explicitly favoured certain 'tribes' or 'ethnic groups' over others, using the divide and rule tactic. This created a sense of superiority by some groups (the so-called majority) and inferiority by others (the so-called minorities). Ironically, when Africans formed 'nationalist' movements to fight colonial rule, the division along the colonially created 'tribal' and 'ethnic' lines were sometimes visible. Bearing in mind that the aim of decolonisation was fundamentally the 'rejection of the civilization of the white man' (Delavignette 1977:131), the 'ethnicisation' and 'tribalisation' of the anti-colonial struggle was regressive, but not surprising 
considering colonial machinations. Therefore, and ironically so, decolonisation, like colonisation, 'contributed to political ethnicity. To begin with, the nationalist movement had mobilised ethnic groups into politics' (Ake 1993:2). This, however, did not stop with the attainment of independence across Africa. It continued into the twenty-first century as political violence often take ethnic dimension.

Across Africa, political leaders, mainly from the numerically large ethnic groups, often take advantage of the rudimentary class consciousness amongst citizens and use 'an ethnic ideology to consolidate a substantial political base' (Ake 1993:3). Ian Khama wanted to exploit this too. Moreover, in Africa, chieftaincy and politics seem to overlap such that some chiefs/traditional authorities oscillate between politics and their hereditary positions. In such a scenario, tribal and ethnic loyalty play a major role in determining who wins the elections between the chief and a commoner. Mafeje rightly argues that 'the problem in Africa is not one of the empirically diversified behaviour but mainly one of ideology, and specifically the ideology of "tribalism" (1971:253). We contextualise some of these issues hereinafter.

\section{Discourses of Tribalism in Botswana, 1975 - 2019}

We identify about six or so periods or occasions in post-independence Botswana in which emotive and inflammatory public debates on tribalism and ethnicity became dominant. These periods are not cast in stone. Immediately following independence, the public debate on tribalism became a dominant feature in Botswana's National Assembly. For instance, the main opposition political parties then, Botswana Peoples Party (BPP) and Botswana National Front (BNF), repeatedly raised justified and progressive concerns regarding tribal equality, mainly the recognition of the languages of the so-called minority groups and their cultures, like it is the case with the 'dominant' Tswana-speaking groups. Despite their legitimacy and progressiveness in a democratic and pluralistic society, such views were seen by the country's ruling political elite, some traditional authorities/chiefs (dikgosi/kgosi) and citizens, mainly from the 'dominant' and 'domineering' Tswana groups, as divisive, anti-nation-building and tribalistic. Thus, as in most post-colonial African states, 'nation-building' in Botswana was achieved under complex circumstances (Dingake 2011; Masire 2006; Mulimbi 2017). 
For instance, in 1975, Kgosi Linchwe II of the Bakgatla-ba-Kgafela revived bogwera (traditional initiation rites) in response to juvenile delinquency and other social ills in the Kgatleng District. Botswana's founding President, Sir Seretse Khama's (1966-1980), response to Linchwe's initiative was a strong criticism of bogwera, which he saw as naked tribalism. Ironically, Khama himself was a chief/kgosi of the Bangwato, but had decided to take active role in party politics. When addressing the nation on Independence Day, 30 September 1975, the unhappy Khama said:

At this point one is tempted to remark about the renaissance of wasteful and long forgotten tribal rituals such as Bogwera. In my view, Bogwera is a divisive ritual. It smacks of the seeds of disunity, coming as it does, at a time when we thought we were winning the battle against tribalism. I would not agree with anybody who might want to convince me that Bogwera is a useful ritual in this day and age. For all it does is to encourage tribal identities and ethnocentrism at the expense of national identity and national unity, and the very fact that this useless primitive ritual has, in some cases, resulted in deaths gives me every reason or right to discourage it as much as I can. In any case, it would be irresponsible of me to encourage the mutilation of our young boys and girls in the bush. There are more useful things to do than running around naked in the forest (Grant 1984:8).

Khama's views were informed by what was happening across Africa where tribalism and ethnicity had led to deadly ethnic conflicts undermining the democratisation process and political stability. He was prettyaware that traditional authorities, because of the massive tribal and ethnic loyalty they enjoy, can use such tribal ceremonies to undermine national cohesion and nationhood. Sandy Grant, a historian and social commentator, wrote that 'When the topic was raised on Radio Botswana, it was vigorously argued both by those who were in favour of it [bogwera] and by those who opposed it. Correspondents to the Daily News [Botswana government newspaper] also showed the extent to which the revival of bogwera had become a nationwide topic' (Grant 1984:8-9). Unlike in much of sub-Saharan Africa, at the time, Batswana (citizens of Botswana), from all walks of life, participated in the public debate openly and freely. Some were very critical of the President. Nonetheless, Kgosi Linchwe and Bakgatla were not deterred by President 
Khama's remarks and rebuke, hence they even organised another bogwera the following year and beyond.

This example also illustrates that free speech is a critical aspect of democracy that has been enjoyed in Botswana from time immemorial. This is engrained in the national consciousness, and forms part of the country's foreign policy as articulated by Botswana's former Ambassador to Australia, Caesar Lekoa, when discussing the country's foreign policy of multilateralism:

First, the concept of peaceful resolution of conflicts in Botswana predates the country's independence (ntwa kgolo ke ya molomo or 'we jaw jaw not war war'). The espousal of this national precept and worldview by established multilateral bodies or international diplomacy, has served as both an inspiration for, and validation of, Botswana's foreign policy on a major fundamental international principle (Lekoa 2019:120).

Some critics, however, contend that Botswana's democracy is in crisis (Mogalakwe \& Nyamnjoh 2017). The 2019 general elections, won by the BDP, for instance, were mired in controversies with the opposition political parties, insisting that there was massive rigging.

The year 1980, the very year Masire succeeded the late Seretse Khama as the President of Botswana, witnessed what can be regarded as a second incident in the tribalism discourse. It took place in the National Assembly. According to Werbner (2004:737), 'a Tswana MP [member of parliament] pronounced nepotism and ethnic favouritism to be the reasons why Kalanga held so many jobs'. The MP lamented and proposed that

this Honourable House deplores discrimination practices in Botswana based on race, tribe, ethnic or political affiliation and urges Government to take measures to discourage these practices (Werbner 2002:737).

A heated and emotive political debate ensued, wherein a leading Nkalanga MP, later an assistant minister, responded:

We sacrificed our language for the sake of national unity. Now you come to Parliament and you say Bakalanga are depriving other 
Batswana of jobs. You are demanding too much (Werbner 2002: 737).

Indeed, the so-called minorities sacrificed their languages and even cultures for nation-building to succeed. Thus, when the decision to 'impose' Setswana as the national language was made, the so-called minorities accepted this reluctantly. For instance, in 1972, when the teaching of Ikalanga language was discontinued in schools in the north, some influential and educated Bakalanga elites confronted President Khama. They saw the decision as akin to cultural genocide (Dingake 2011). Their position was deemed too political and was viewed by the Tswana-speaking as tribalistic. Tribalism and ethnicity debates are invariably embedded in the politics of resource distribution, and opportunities, such as jobs and education, hence similar issues arise in Botswana.

A third period in the discourse of tribalism and ethnicity can be traced to 1982 when the Bank of Botswana introduced the Pula currency notes, with the portraits of Khama's successor, Masire, replacing that of the former. Although this was in line with the Constitution of Botswana, the development was met with fierce condemnation, resistance, and tribal slurs by Bangwato tribal leaders, who were worried ignorantly that Masire was plotting to usurp the presidency of Botswana from Seretse Khama's son, Ian Khama. They believed that Masire was only holding the fort for Ian. Thus, following Khama's death, some Bangwato elders wanted Ian to become their chief and ultimately the President. They confused the presidency with hereditary bogosi (chieftaincy) as they insisted that Ian should succeed his father as the President. In Bangwato's tribal territory, 'Masire was dismissed as a nonentity for his hyena (phiri) totem, because even among Masire's Bangwaketse tribe, those who venerate the hyena (Babinaphiri) were lowly regarded' (Makgala 2008). Reports emerged that in the Central District, some people refused to accept the new Pula notes and even destroyed them in some cases. In Mahalapye, there were demonstrations in the streets by some 200 -strong BDP members. Some Bangwato tribal elders made their anti-Masire feelings known:

Some people in the southern part of the country did not appreciate the Bangwato's attitude and branded them tribalists. This angered the Bangwato Tribal Authority [Regent], Mokgacha Mokgadi, who complained to President Masire during a public meeting in Serowe (Bangwato capital) that some Cabinet Ministers in Botswana and the 
South African media portrayed the Bangwato as subversive. The apartheid regime in South Africa tried to capitalise on the situation in order to destabilise Botswana. For instance, in October 1982 the regime distributed leaflets suggesting defiance by the Bangwato to Masire's presidency.

As late as 1984, the issue of Masire's portrait was still raging in Serowe. For example, at a meeting addressed by Botswana National Front (BNF) President Dr Kenneth Koma said in January 1984 in Serowe, 'two prominent members of the Bangwato royal family, Messrs [Peto] Sekgoma and Keaboka Kgamane, joined the BNF because they said they had lost confidence in the BDP'. They complained that 'the Minister of Public Service and Information, Mr. D.K. Kwelagobe once promised the people of Serowe that the government would rectify the mistake of changing the currency portrait and that the One Pula note would not be changed. But this they said had been changed without consulting the people' (Makgala 2008:48).

The matter became a political issue in the 1984 general elections with the BNF trying hard to capitalise on it, but failed, as the BDP emerged victorious and retained all the parliamentary seats in the Central District. This region has always been a stronghold of the BDP since its formation in 1962. It has proved quite difficult to dislodge it over the years, although the situation changed in 2019. Should former President Ian Khama continue with his campaigns and recruitment drive in that region, the BDP might not be able to retake the seats it lost in the 2019 general elections. Moreover, the opposition parties seem eager to work together in the next (2024) general elections.

A fourth example in the discourse of tribalism was/is what came to be known publicly as the 'LENO Affair' in 1986. Botswana was beginning to experience a substantial boom in the construction sector as revenue from diamond mining started to make a significant impact on the national economy. As a result, there were planned huge lucrative real estate developments in some parts of Gaborone, the capital city, known as the Government Enclave. A group of largely Tswana-speaking senior civil servants, MPs and cabinet ministers, armed with inside information, formed a company called LENO in order to position themselves for the massive opportunities opening up in the sprawling Gaborone and other parts of the country. A factional conflict between LENO shareholders led to a lawsuit handled by an Nkalanga lawyer, and the 
company's 'hidden tribal agenda' became public knowledge, resulting in heated debates in the local media (Werbner 2004).

A predominantly Bakalanga owned company called Land Holdings was formed to rival LENO and break its intended monopoly over the lucrative real estate projects. Although there was a smattering of Ikalanga-speakers in LENO, Land Holdings also had a presence of Tswana-speakers (Werbner 2002). Tribalism, imagined or real, became dominant in the private and public discourse of the Leno-Land Holding rivalry. Despite these public spats of tribalism in the local media, the issue largely became an elite affair. Interestingly, the same bickering elites continued to work together for personal economic and business benefits. They could not allow tribal bigotry to destroy their business relations and interests. For instance, the Bakalanga elites, although vocal on their demands for tribal equality, are not so naïve to want to achieve this through bloodshed and self-destruction, observes Richard Werbner (2004). In sub-Saharan Africa, tribalism and ethnic violence are linked directly and indirectly to the competition over resources, jobs and opportunities (Daley 2006; Nasong'o 2015), hence the Leno-Land Holding rivalry was not an exception.

A fifth discourse of tribalism was in 1998 at the height of the BNF factional fighting. For some time, the party was polarised between the conservative left-leaning old guard and 'progressive liberals', with the latter winning handsomely at the party's 1997 elective congress held in Gaborone. The old guard rejected the results arguing that their opponents had rigged the elections. Dr Kenneth Koma, the leader of the party, sided with the old guard and his taking sides worsened an already volatile situation. An anti-Koma critic and a University of Botswana (UB) academic, Log Raditlhokwa, pointed out that since Festus Mogae (who was earmarked to succeed Masire in April 1998) and Ian Khama (who planned to quit the army on the eve of Masire's retirement) were Bangwato, and so was Koma, the latter wanted to perpetuate 'Ngwatoism' (Raditlhokwa 28 January 1998) in Botswana's political leadership. To Raditlhokwa, this was an act of tribalism by the Marxist Koma. Raditlhokwa was severely castigated by a Koma loyalist, Kingdom Ipotseng, who charged that 'To label Dr Koma a tribalist is a very unfair and extreme form of dishonesty. Raditlhokwa should show that Dr Koma's interests are not narrow. Koma is a revolutionary Pan Africanist whose interests transcend class and ethnicity' (Ipotseng 6-12 March 1998). 
In April 1998, when the newly inaugurated President Festus Mogae (1998-2008) was in the process of consultation with the MPs for the appointment of his Vice President, the BNF MPs caucused to give the BDP veteran parliamentarian, David Magang, the nod. However, after Mogae met with Koma, the latter endorsed Ian Khama. It is alleged that Mogae had promised him (Koma) the introduction of party funding by the state, which the opposition parties desperately needed and had long called for, but in vain. On finding this out, the BNF MPs were greatly incensed and saw this as tribalism on the part of Koma because both Koma and Mogae were Bangwato (originally from Serowe) and Ian Khama was their kgosi. This further exacerbated factional tensions in the BNF, which escalated into a violent confrontation at a party gathering in Palapye in April 1998. The BNF liberals suspended Koma from the party's leadership and the matter ended up at the High Court, which ruled in Koma's favour. Raditlhokwa, who was part of the anti-Koma faction, went on the offensive, restating his views of Koma as an unrepentant tribalist:

Koma's Achilles' heel is that he has a profound and self-incapacitating love for his two most powerful tribesmen, President Festus Mogae and his vice, Lt. Ian Khama. Their ascendancy to top positions in the BDP and government has completely disarmed him. He no longer has the zeal to spearhead a fierce struggle against the BDP. He would rather fragment and enervate the BNF to give his favourite tribesmen and the BDP a free ticket to power in 1999 [...] It should be understood that despite all his camouflages, Koma is not only a conservative traditional patriarch; he is also a tribalist at heart (Raditlhokwa 1-7 May 1998).

In sub-Saharan Africa, political leaders, especially those from the largely populous regions, exploit ethnic and tribal loyalty to win votes (Ake 1993; Opondo 2014). In Botswana, for instance, these two chiefs-cum-politicians, Seretse Khama and Bathoen Gaseitsiwe, a former BNF MP for Kanye, were voted into power mainly because of tribal and ethnic loyalty. Thus, tribal loyalty and ethnic sentiments often play a key role in politics, especially in the conservative rural areas. Raditlhokwa's views about Koma were repeated by one P. Botlhale, who stressed that 'Koma is incorrigibly a believer in tribalism. He wants the BNF to be ruled through Ngwatoism as in the BDP' (Botlhale 12 June 1998). With factional conflict in the BNF beyond redemption, the 
progressive liberals, who included 11 of the $13 \mathrm{BNF}$ parliamentarians, left the party to form the Botswana Congress Party (BCP). This was a terrible blow to the BNF as the BDP easily won the 1999 general elections.

A sixth period of the discourse of tribalism was in 2000, when, following years of incessant demand by the so-called minorities for tribal equality:

the government of Botswana finally constituted a Commission of Inquiry to consult Batswana on the old grievance that sections 77,78 and 79 of the Republican Constitution discriminated against ethnic minorities. The consequence was heated and often inflammatory public debate by those against the cited sections of the Constitution and those supporting the status quo. The debate soon degenerated into Bangwato-Kalanga skirmish characterised by vicious accusations and counter-accusations of tribal bigotry, name calling, and war talk. The 1994 Rwandan genocide was often evoked as likely to be repeated in Botswana (Makgala, Chebanne \& Bolaane n.d).

The Commission of Inquiry, referred to above, was appointed by President Mogae. It was chaired by a former Cabinet Minister, Patrick Balopi, hence the Balopi Commission. Some influential Tswanaspeakers strongly campaigned against those who looked up to the Commission for redress of the pastinjustices and constitutional recognition. The repeat of the Rwandan genocide is highly unlikely in Botswana because the country's nation-building exercise seems consolidated - thanks to the democratic tradition and multilayered ethnic identities that sustain peace (Makgala, Chebanne \& Bolaane n.d). This, however, does not suggest that the Botswana nation-building exercise has not faced some deep-seated and complex challenges. For instance, the so-called minority ethnic groups still demand language rights and equal representation at Ntlo ya Dikgosi (House of Chiefs).

We note that tribalism was/is not only limited to the six occasions, discussed above, and the 2019 one. There were few other instances. For example, soon after independence, the then main opposition party, the BPP, MPs raised concerns over the marginalisation of the so-called minority tribes, but were dismissed by the majority BDP MPs as trying to ferment tribalism. The later main opposition, BNF's, similar concerns suffered the same fate at the hands of the BDP. 
In the late 1970s, one MP alleged, in the National Assembly, that there was a deliberate campaign by senior Bakalanga officials at the Ministry of Education, to ensure that the Bakalanga applicants for government bursaries/scholarships had a groundnut (Bakalanga delicacy) drawn on their applications, in order to ensure the success of their applications (Werbner 2002). The alleged Bakalanga nepotism endured for a long time and was even bandied around during the tribalism debate of 2000, noted above. Historically, severe land shortage among the Bakalanga in the North East District led to parents ensuring that their children pursue education for a better life.

Other examples of the discourse of tribalism emerged when cabinet ministers from the so-called minority tribes rebuked, in public, or suspended chiefs of the so-called major tribes. This happened in the mid-1980s, when Minister Lesedi Mothibamele, from Kgalagadi District, rebuked Kgosi Linchwe II in Mochudi for an alleged insubordination. A similar development took place in the early 1990s, when Minister Chapson Jabavu Butale, from the North East District, suspended Kgosi Seepapitso IV of the Bangwaketse (Gulbrandsen 2012). These developments led to the exchange of tribal slurs, directed to the said ministers, by the affected ethnic groups (merafe) and their tribal leaders. It is highly likely that these reprimands were sanctioned by the President and his Cabinet. ${ }^{2}$ Since independence, the chiefs have greatly lost their powers to the political ruling elite, even though they still command massive loyalty from their subjects, as we show herein.

Botswana's political landscape and elections have always had a tribal dimension at internal party organs and primary elections, as well as the national or general elections. In the past, for instance, the BPP was regarded, in some quarters, as a regional party, with a large following in Francistown. For years, it only managed to win few council seats in Francistown and the North East District. Observers of the tribal dimension in party elections and development indicate that:

The scramble for economic opportunities has fuelled debilitating factionalism within both the ruling and opposition parties over the years. In some instances tribalism was mobilised in intra- and inter-

${ }^{2}$ We are grateful to Professor Monageng Mogalakwe for this point (email communication with Moganeng Mogalakwe 9 January 2020). 
party elections for positions of influence even though voters are more interested in service delivery than traditional ethnic issues [...]

Despite very limited support for any kind of tribal/ethnic agenda in Botswana politics, it has endured to a limited extent as some segments of the elite have desperately tried to utilise it for personal advantage. For the most part, one could consider the tribal agenda supplanted by cross-party defections, seemingly in pursuit of political and economic success (Makgala \& Botlhomilwe 2017:1).

The final illustration in the Botswana's tribalism discourse, which is the primary focus of this paper, took place within the context of the 2019 general elections. Ian Khama's political activism was at the centre of this development. The next section provides a brief background on him.

\section{Ian Khama's Political Heritage}

Ian Khama, also known as Seretse Khama Ian Khama, is the son of Botswana's founding President and a de facto kgosi of Bangwato, Seretse Khama. Ian was born in England in 1953, when his father was in exile there for marrying a white woman, Ruth Williams (later Lady Khama). A history of how the Bangwato came to dominate Botswana's political landscape and Ian's political heritage are critical when discussing his political activism. We trace the political influence of the Bangwato leaders to 1885 , when a British military general, Sir Charles Warren, leading a strong contingent of British troops, declared a protectorate status over the previously independent Tswana kingdoms. Whereas other dikgosi, whom Warren met, were suspicious of the British motives and accepted the so-called protection reluctantly, Khama III, of the Bangwato, readily cooperated. A Christian fundamentalist, he became quite popular with the British missionaries of the London Missionary Society, who called him 'Khama the Good' and 'Khama the Great'. He became the most respected African ruler of his time attaining 'a unique status in the British Empire' (Parsons et al. 1995:9).

The constitution that led to the formation of the Union of South Africa in 1910 had a provision for the incorporation of Botswana, Lesotho and Swaziland into South Africa. Aware of the harsh conditions under which Africans lived in South Africa, characterised by the loss of their land, political and economic rights, as well as racism, dikgosi in Botswana vigorously 
campaigned against the incorporation. Khama III's involvement seemed decisive (Parsons et al. 1995:10).

He died in 1923 and was succeeded by his son, Sekgoma II, who died after about a year in office. However, his son and the heir apparent, Seretse Khama, was only four years-old, and his uncle, Tshekedi Khama, became a regent in 1926. Tshekedi was a consummate negotiator and skilled administrator, which the British administration valued greatly. He pursued, with more vigour, the resistance against the planned incorporation into South Africa. Tshekedi also protested South Africa's occupation of Namibia (Crowder 1987) and attempts by the unpopular white-controlled Federation of Central Africa, made up of Northern Rhodesia (Zambia), Southern Rhodesia (Zimbabwe) and Nyasaland (Malawi), to incorporate Botswana (Jackson, 1999). Magang (2015) describes Tshekedi as the sharpest statesman in Botswana's history.

In 1949, whilst studying in England, Seretse married Ruth Williams, and this caused a great uproar in apartheid South Africa and in Britain. Tshekedi was also totally against the marriage, which divided the Bangwato into two hostile camps: the pro-marriage group, supporting Seretse, and the anti-marriage rival, aligned to Tshekedi. The British exiled Seretse to Britain, while Tshekedi went into a self-imposed exile in the Bakwena tribal territory. Nevertheless, the marriage made Seretse very popular throughout Botswana and beyond, particularly among the oppressed blacks in South Africa, where the marriage was loathed by the apartheid regime. Seretse became so popular among the South African black communities that praise songs were sung about him, and picture framers made good business selling his photos, which adorned many houses (Dingake 1987). Back in Botswana, 'When Seretse Khama cofounded and later led the BDP to victory in the first general elections in March, 1965, he was already a legend; a man larger than life, thanks to this marriage, which had given him much political and social clout, and enabled him to eclipse politically the nationalist luminaries of that time, the likes of Philip Matante, Motsamai Mpho, and Kgalemang Motsetse' (Mogalakwe 14 October 2019).

In the early 1970s, the modestly educated Ian Khama joined the paramilitary Police Mobile Unit and later went for military training at Sandhurst Military College in England. In 1977, the Botswana Defence Force (BDF) was established mainly to defend the country against military incursions in the north-eastern regions by the Rhodesian troops pursuing freedom fighters into 
Botswana. Seretse Khama appointed Ian Khama a brigadier and deputy commander of the BDF in his twenties. Some critics have accused Seretse of nepotism in appointing his son to such a high position in the newly formed army over the heads of more qualified and experienced professionals.

On 27 February 1978, the Rhodesian troops crossed the border into Botswana and ambushed the BDF officers around Lesoma village in the Chobe District, and 15 BDF soldiers perished in the ambush, which shocked and aggrieved the nation greatly. The tragedy saw Ian Khama's star rising beyond belief. Popular tradition immortalised him into the national lore as it was claimed that out of feat of rage, he ventured deep into the Rhodesian territory and single-handedly massacred large numbers of Rhodesian soldiers. In the North East District, in the villages along the Botswana-Zimbabwe border, such as Mapoka, Moroka and Zwenshambe, there is a popular public myth that Ian had wanted to cross the border into Zimbabwe to 'kill' Ian Smith, following the incessant Rhodesian incursions. The myth goes on to say that his father, Seretse, refused. These myths contributed to Ian's mysticism and popularity, mainly among the rural folks.

In 1979, Seretse installed Ian as the kgosi of Bangwato, which also cemented his popularity throughout the country. When Seretse died in office, in 1980, he was succeeded by his Vice President, Masire. Some Bangwato believed that Masire was holding office temporarily for Ian 'to enable him to develop a career in the army, grow up and eventually take over as President' (Molomo 2001:101). Masire, some argue, 'had to appease the Bangwato by appointing Seretse's cousin, Lenyeletse Seretse, to the position of VicePresidency' (Nyathi-Ramahobo 2002:24). Interestingly, upon his inauguration, on 1 April 1998, President Mogae appointed Ian Khama 'Vice-President and Minister of Presidential Affairs and Public Administration. [This] was well received by Bangwato. They perceived the move as grooming their heir apparent to eventually take-over the high[est] political office' (Molomo 2000:101), which he did on 1 April 2008. When Ian Khama was recruited into the BDP in 1998, from the BDF, the party was inundated by debilitating personality-driven factionalism, which had started in 1991. Thus, Khama was seen as a neutral unifier, who would help the party retain power in the 1999 general elections. The electoral threat posed by the BNF fizzled out as it experienced a major split in 1998, leading to the formation of the BCP, as noted. Consequently, the BDP won the 1999 elections and retained power easily. 


\section{5 'Deculturalisation' and the Presidency of Ian Khama}

Amongst the Tswana, traditionally, an incumbent kgosi was expected to ensure that the heir, when old enough, attended the kgotla (seat of traditional government) to learn how cases were tried and was instructed in law and custom (Schapera 1938). However, with modernity, by the 1920s and 1930s, a new generation of dikgosi started getting into office replacing their ageing fathers. These were 'young men educated for most part in schools outside the Protectorate, and so cut off from adequate first-hand experience of tribal government and jurisdiction' (Schapera 1940:67). Largely, these dikgosi, among whom was Tshekedi Khama, were not de-culturalised from the Tswana way of life and, thus, fitted quite well into it in many respects. 'Deculturalisation' is the conscious and unconscious process of 'destroying a people's culture and replacing it with a new culture' (Spring 2010:8). In this paper, it means loosely a tribal leader who has not been socialised into his/her people's culture or African way of life, which includes language. Kgosi Bathoen II of Bangwaketse, who had studied in South Africa, saw himself as the authority in Tswana custom (Masire 2006). 'Since culture replicates the identity of a people - language, belief, norms, and values of a people, deculturalization is therefore a grave thing to occur to any human society', notes Kekeghe (2020:4).

Seretse Khama studied at Tiger Kloof College and University of Fort Hare, both in South Africa, and Oxford University, but grew up in Serowe and often visited his village during school recess. His formative years were spent within the Tswana cultural milieu and he was able to learn and embrace it (Parsons et al. 1995). He also became involved in the running of tribal affairs as a member of the Bangwato Tribal Council, starting in the 1950s, upon his return from exile. In 1960, the Legislative Council was formed in Botswana and Seretse, together with Masire and others, became members. The Tribal Council and Legislative Council were democratic institutions where members were elected, and debated issues along a majoritarian consensus decisionmaking process. Seretse even continued this approach as the President, entrenching a democratic state, when much of Africa fell to one-party states and military dictatorships, not to mention devastating tribalism.

On the other hand, Ian Khama became the opposite of his father, Seretse. He was born in England outside the Setswana cultural milieu. Ian also 
studied outside Botswana and does not seem to have had interest in embracing the Tswana culture, let alone the chiefly office and its associated responsibilities. There is a perception among some Batswana that his English mother was responsible for this kind of upbringing of Ian. He became deculturalised from the African life. Deculturalisation, we reiterate, is 'a process that leads to the deletion of the cultural orientation of a people to uphold and practise a new one' (Kekeghe 2020:4). Ian became a police officer and a military commander, at a young age, and both institutions are inherently non-democratic. An anonymous letter appearing in Mmegi Monitor, in July 2000 , stated that 'Ian is a white man and he does not know anything about... tribalism. He was raised by a white woman' (Concerned Motswana Citizen 1117 July 2000). Despite being a kgosi, Ian never bothered to learn the national language Setswana seriously, until he became the Vice President in 1998, in his forties.

In his inaugural speech in April 2008, Ian Khama outlined his roadmap, made up of what he called 'Four Ds', namely, 'Democracy, Discipline, Dignity and Development'. He later added a fifth D for 'Delivery'. In his inaugural speech, Ian Khama said that he joined the army in order to defend the country's democracy, a claim that has been disputed by, among others, Mogalakwe and Nyamnjoh (2017) and Motlogelwa and Civilini (2015). As President, he was accused of being an intolerant unilateralist, despot, greedy, unpatriotic, and openly practising nepotism and favouritism. Elite corruption escalated, largely unchecked, during his presidency (Mogalakwe \& Nyamnjoh 2017). Ironically, when elite corruption started taking root in Botswana in the early 1990s, Khama's mother, Lady Khama, commented critically on the vice, in 1993, and emphasised the role of Seretse Khama as a kgosi. She lamented: 'Corruption has now crept in, also greed. We didn't have greed before [...] Because Seretse had been a chief he had an ingrained sense of responsibility [...] He was against extremes. He wanted to bring everybody up to the same level [...] Seretse would be sad if he were alive today' (Hermans 1993:7). Interestingly, things worsened under her son, Ian Khama's, watch, perhaps because he had not been socialised into bogosi, but was 'de-culturalised'.

When Ian Khama became President, he established the Directorate of Intelligence and Security Services (DISS) immediately, which became a greatly feared entity. Among other appalling crimes, it was accused of corruption and extra-judicial killings of members of the public. Khama was also accused of the militarisation of the civil service (Good 2010). He 
introduced populist and personalised programmes (Harmer 2016). Khama was also accused of supressing the private media, and he never held even one media conference throughout his ten-year tenure (2008-2018). During his tenure, Khama was also seen as undermining the independence of the judiciary, among others. His 'intolerance' within the BDP led to the party's first split, in 2010, when the disillusioned party members left to form the Botswana Movement for Democracy (BMD).

Nonetheless, to his credit, Ian Khama, unlike his father in 1975, encouraged and supported the revival of cultural ceremonies, such as bogwera, by different merafe/tribes mainly for cultural tourism. But he also proved to be an authoritarian leader, as instanced by his refusal to consult important stakeholders, such as the public service trade unions under their umbrella, the Botswana Federation of Public Sector Unions (BOFEPUSPU), on their demand for $16 \%$ salary hike in 2011. This culminated in the longest civil service strike in Botswana's history (Makgala and Malila 2014). Khama also undermined the Public Service Bargaining Council (PSBC) routinely, which eventually collapsed, by pronouncing salary increments at kgotla meetings and outside the collective bargaining structures. BOFEPUSU went on to assist the opposition parties to unite, which they had failed to do since 1966, and form the Umbrella for Democratic Change (UDC). The BCP opted out of the UDC. The general elections, held on 24 October 2014, proved to be the most competitive ever. The BDP, which was used to easy victories, faced a tough contest from the UDC. Eventually, the opposition parties secured 53\% of the popular vote and the BDP's popular vote plummeted to $47 \%$. It, however, held onto power through the first-past-the-post system, winning 37 out of the 57 parliamentary seats. The UDC obtained 17 seats and the BCP three seats. This poor showing by the BDP was blamed on Khama's leadership style. When the BCP joined the UDC after the 2014 elections, some political observers and the private media concluded that the UDC was poised to toppling the BDP from power in the 2019 elections (Makgala 2019).

Khama's leadership style also concerned former Presidents Masire and Mogae so much that they publicly condemned him even outside the country. The BDP and its government defended Khama quite strongly. They told the former Presidents, in clear and emphatic terms, to allow Khama to rule undisturbed. Khama also 'changed' Botswana's foreign policy of 'silence diplomacy' to what critics called 'rooftop diplomacy'. His government openly condemned other governments, including major powers, such as the United 
States (US) and China. Khama even greatly angered China by embracing and inviting to Botswana, the exiled Tibetan spiritual leader, the Dalai Lama, whom China considers a separatist and a rebel leader (Ditsheko 2019). Although the Dalai Lama failed to come, owing to health problems, Khama visited him after his term ended. Many saw this as a direct challenge to both the governments of China and Botswana.

Khama also never attended any meetings of the African Union and the United Nations. Not surprisingly, he attended the Commonwealth meetings, where the ceremonial Head is the Queen of England, his place of birth. ${ }^{3} \mathrm{He}$ also supported the International Criminal Court strongly, which most African leaders condemned, claiming that it only targets Africans. This attitude worked against Khama's Minister of Foreign Affairs and International Cooperation, Pelonomi Venson-Moitoi, when she applied for the chairpersonship of the African Union. She campaigned with little support from Khama in 2016 and 2017. Robert Mugabe blamed Khama for Venson-Moitoi's loss.

\section{BDP 'Elective' Congress in Kang: Presidential Succession and Tribalism}

The succession from President Ian Khama to his Vice President, Mokgweetsi Masisi, was hailed as a continuation of Botswana's tradition of peaceful transition from one President to another. President Khama, when bidding Batswana farewell during the nation-wide and televised kgotla meetings, lauded the 'smooth' transition and praised Masisi as his best choice, who will become a great President. However, the hype quickly faded as Khama and Masisi fell out and embarked on a public denunciation of each other and accused each other of promoting tribalism. Feeling betrayed, Khama vowed to 'topple' Masisi from the Presidency. Speculations were rife, in the local media, that Masisi disregarded their alleged 'gentleman's agreement' to appoint Khama's young brother and the minister of Tourism and Environment, Tshekedi Khama, to the Vice Presidency.

Masisi later announced that Ian Khama's leadership style nearly cost the BDP power in 2014, leading to its decline in popularity (Masokola 2-8 March 2019). He was also determined to reverse many of Khama's 'unpopular' programmes and his general approach to leadership. Among these was the

${ }^{3}$ We are grateful to Professor Monageng Mogalakwe for this observation. 
disarming of the game rangers in the northern part of the country, who had been armed with arms of war by Tshekedi Khama to combat rampant poaching. Masisi also lifted the hunting ban, which was introduced under the Khama administration. The ban was said to have led to overpopulation of elephants and other big game, resulting in serious human-wildlife conflict. The Khamas responded by mobilising influential western media and conservation lobby groups to condemn the lifting of the hunting ban. Masisi also had to mend relations with neighbouring countries in the region, as well as China, which had been strained during the Khama presidency.

While the BDP's constitution allows for the president to be challenged, this has always been avoided. However, in late 2018, Venson-Moitoi shocked many when she announced that she would challenge Masisi for the party's presidency in the 2019 elective congress. Some suspected Khama to be behind this turn of events, especially that he openly backed Venson-Moitoi. Masisi responded by sacking her from Cabinet where she was the Minister of Foreign Affairs and International Cooperation. Venson-Moitoi is from Serowe and had previously worked for the Bangwato Tribal Administration. Her bold decision to challenge Masisi was condemned by many as regionalism and tribalism, fermented by her and Khama. Contrarily, her supporters promoted her as a woman candidate for women empowerment, which is seriously inadequate in Botswana's political leadership. Many people, across the political divide, felt that they were no longer prepared to have yet another BDP president and possibly the President of the country coming from Serowe. The village has had three Presidents (Seretse, Mogae and Khama) and four Vice Presidents. There was a feeling that other regions also deserved the same privilege. Masire had been the only President from the southern part of Botswana and Masisi the second. Among those who expressed apprehension of Venson-Moitoi's candidature was former President Mogae, who argued that there was no need to impose another Serowe native into the Presidency. He decried that VensonMoitoi was being imposed on the BDP at all cost under the pretext of women empowerment.

At a BDP event in Tlokweng, Masisi was reported to have said that there were some tribes that think that they are superior to others. He gave example of the 1994 Rwandan genocide as a result of such an attitude. Khama, who felt that a damaging accusation was levelled against him, did not take kindly to this, and, instead, accused Masisi of promoting tribalism. He lashed out at Masisi by saying that 'the way our country is run now, it may go the way 
of Rwanda, Sudan, Somalia and Venezuela if tribalism is not nipped in the bud now before it even raises its ugly head' (Gabathuse 1 March 2019). For her part, Venson-Moitoi, who was addressing the same meeting as Khama, in Serowe, was equally 'concerned by the tribalism charges. She said the unending tribal utterances by the sitting President distressed her' (Gabathuse 1 March 2019).

Some southerners saw Venson-Moitoi's campaign as regionalism. Northerners were accused of trying to reclaim political power and return Ian Khama to the Presidency through the backdoor. However, the 'north vs south' theory was dismissed by Venson-Moitoi's replacement at the Ministry of Foreign Affairs and International Cooperation, Unity Dow. Dow wrote in social media that 'There is no North v South War. Those selling this are trying to bukata [slang for deceive] you from seeing the real war. They are hoping that you will be blinded by tribal affiliations and take sides on that basis'. More than once, Khama had argued that 'our constitution does not prevent him from coming back, it only prevents him from continuing. He then cited the [Russian President Vladimir] Putin example, saying how it was perfectly legal for him to return after a break', recalls Dow. Masisi and his faction launched a campaign of intimidation and victimisation of Venson-Moitoi's supporters. Venson-Moitoi was even 'xenophobically' branded Lenyasa because of her father's Malawian origin. In a deeply patriarchal society as Botswana, where the previous modest achievements at women empowerment in politics was severely eroded during Khama's presidency (Nasha 2014), there was also a view that Venson-Moitoi's campaign was sabotaged by sexists masquerading as anti-tribalism (Morima 15 January 2019). The victimisation of VensonMoitoi heightened to a point where she instituted legal proceedings at the High Court, but lost the case, and later withdrew from the race held in Kang. She cited tribalism and victimisation of her followers, among other issues. As a result, Masisi was declared the winner unopposed. In this respect, Masisi's approach was not different from that of Ian Khama and other African leaders. Interestingly, but not surprisingly, local and international Pentecostal 'prophets of doom' had a field day 'prophesising' that the Khama-Masisi tension would plunge Botswana into anarchy.

However, many people, including the private media, felt that Khama should leave Masisi to govern the country undisturbed as much as he did during his tenure. Khama's repressive rule, characterised by fear, may have also contributed to this view. Not to be left behind, the Association of Former 
Members of Botswana Parliament, whose members come from various political parties, condemned Khama's 'harassment' of Masisi and called all and sundry to reject Khama's antics, which they said had the potential to bring instability to the otherwise peaceful Botswana. 'We observe with regret that his (Khama's) sympathy-seeking antics are fast turning into promotion of regionalism and tribalism', the former legislators cautioned. (Club of Mozambique 15 May 2019)

\section{Formation of the BPF and Khama's 'Heightened Tribal Campaign'}

After the premature and demoralising end of Venson-Moitoi's run for the BDP's presidency in May 2019, Khama went to his 'tribal fortress', Serowe, to consult his uncles and tribe/morafe on the way forward. At a well attended meeting held at Serowe Show Grounds, he complained about Masisi leading the country astray and for using the DISS to instil fear in citizens. These were the same accusations levelled against Khama during his presidency. The purpose of the Serowe meeting was to gauge the mood of his morafe. He asked whether he should quit the BDP or not to which he got a thunderous approval to quit his father's party. Few of his uncles and key Bangwato Tribal Administration officials had boycotted Masisi's meeting in Serowe previously, but made sure that they attended Khama's meeting as their kgosi (The Patriot 20 October 2019). Tribal loyalty was at play. Khama's loyalists went to the extent of coining a slogan or a tribal battle previously cry 'Eseng mo go Kgosikgolo' ('Don't Mess with our Paramount Chief') printed on T-shirts with his face.

Not long after his first meeting, Khama convened another meeting at the same venue in Serowe. In his tirade against Masisi, he declared that 'They want to bury me, my family and all of you', and this attracted a lot of media attention and comments from critics. Khama then announced his resignation from the BDP formally, and threw his party membership card on the ground symbolically. This was followed by some BDP card-carrying members, who hurried to throw theirs at the same spot. Khama declared openly that his political crusade was to topple the BDP through cooperation with the main opposition party, the UDC. Despite having loathed the opposition and suppressed the private media, he now used them (including South African media), as allies in his quest to dislodge Masisi and the BDP from power. At 
the Serowe meeting, 'Khama and his tribesmen and women took turns to spew out diatribe and barbed wires (sic) aimed at the administration of President Mokgweetsi Masisi and the party executive leadership and in the process sowing seeds of tribal politics' (Gabathuse 10 May 2019). Gabathuse further notes that 'The grand plan is to exploit the reality that the colossal Central District Council (CDC) has from pre-independence to date, proven to be the BDP's unshakeable stronghold'. The Central District has, by far, the largest number of constituencies in the country, about 19 out of 57 nationally. Therefore, Khama seemed to bank on this and wanted to exploit it to paralyse the BDP.

Khama and his followers later formed a new political party, the BPF, and he became its 'patron'. Many dismissed it as a narrowly focused tribal project and made snide remarks calling it 'Bangwato Patriotic Front'. Nonetheless, the BPF soon started recruiting members from the BDP and many sitting councillors and others, mostly disgruntled BDP activists, who had lost the party's primary elections for the 2019 general elections, quit it and joined the BPF. Others joined sensing opportunities in the new political entity. Biggie Butale, a Nkalanga from Masunga, who lost his parliamentary seat in the BDP primary elections in the Tati West Constituency to Simon Moabi, but blamed this on Masisi, became the interim president of the BPF.

To counter the view that the BPF was a Bangwato tribal party, its inaugural meeting was held in Kanye in the southern part of the country. Khama was even alleged to have tried to call a meeting of more than 10 of the areas dikgosana (headmen) prior to the launch in order to give the BPF project a wider and popular appeal. It was also alleged that he had promised each a substantial amount of money for attendance (Ramatiti 8 July 2019). In the public, some complained that Khama was undermining Kgosi Malope II of Bangwaketse by holding a political rally in his tribal territory and trying to lure his dikgosana behind his back. Duma Boko, the UDC president and a Xhosa from Mahalapye in the Central District, informally embraced Khama, who launched some UDC candidates. This was greatly resented by some party members and voters (Brown 2020).

The BDP won the 2019 elections by 38 , of the 57 parliamentary seats, mostly in the southern part of Botswana, where the UDC had made significant gains in the 2014 elections. Some BDP winning margins were so massive that the UDC, which got only 15 seats, protested that there was massive rigging, and naturally Khama supported their claims. Khama was among the first who 
hinted or suggested that the UDC had been cheated in the elections, and urged them to challenge the results at the courts. His BPF won only three seats, all from his Serowe heartland, while the Alliance for Progressives (AP), BMD's splinter party, salvaged just one seat. The BDP got some $53 \%$ of the popular vote, while the combined opposition received $47 \%$, with the UDC registering $36 \%$ of that. Some interpreted the massive win for the BDP in the southern part of the country as a rejection of Khama and his alleged tribalism, as well as the Khama-aligned UDC (Brown 2020). This perception was reminiscent of the 1982 debate when the southern part of the country stood against Bangwato and accused them of tribalism when they rejected the bank notes with Masire's portrait on them, as argued. The BPF did well in Serowe, and it is evident that Bangwato voted for the party because of Khama's massive influence. Similarly, Khama assisted the UDC to campaign and win some constituencies in Shoshong, Palapye and Mahalapye, among others.

\section{Perspectives on Ian Khama's 'Induced Tribalism'}

Two schools of thought emerged as the debate on Khama's political campaign against Masisi and the BDP intensified....the perceptions and arguments that Khama was tribalistic in mobilising Bangwato against Masisi and the BDP was challenged by the private Sunday Standard newspaper. In an insightful article, which appeared in May 2019, but without a by-line and having the title: 'Khama Too Culturally Western to be Tribalistic', the author explained and emphasised Khama's deculturalisation or detribalisation and his decades' long isolation from the Bangwato community:

Khama has never hesitated to leverage his royal position to bolster his political standing. Out of real fear that his political star is waning, he addressed a political rally at the Serowe showground last week that had been deceptively advertised as a consultative tribal meeting. In his capacity as Bangwato 'kgosikgolo' (an officially non-existent title), Khama invited 'Bangwato' to a meeting where the only item on the agenda was political, not tribal. Following that meeting and now more than ever, some have pinned an impossible label on Khama - 'tribalist'. Others see him as a tribal (Mongwato) supremacist who is hellbent on tribalising a public good - the state presidency. The problem with casting Khama's antics in tribal terms is that from an objective, 
evidence-based perspective, he has never been part of Ngwato culture. More western than African, Khama is merely using tribal identity no differently from the way British colonialists used it - as a wedge to divide and conquer black Africans.

[...] there is abundant evidence that the bi-racial Khama is not personally invested in any tribal agenda of the Bangwato. Evidence is as abundant that he doesn't participate in the tribal life of the tribe that he is kgosi (supreme traditional leader) of. Khama has also set deeply problematic records that undermine Bangwato culture. He is the first Bangwato kgosi in the tribe's history whose principal conversational language is not Setswana and who doesn't speak proper (never mind idiomatic) Setswana [...]

[...] He is the first Bangwato kgosi whose principal residence is hundreds of kilometres away from his royal seat of power. A deeppocketed man, Khama doesn't even have a house in Serowe but stays at the family house which wouldn't afford him the comfort of his Gaborone residences (Sunday Standard 20 May 2019).

The author fell short of labelling Khama a 'racist'. As President, the author avers, Khama 'pursued a foreign policy that put western interests before those of the African collective, whom Bangwato are part of as Botswana citizens'. The author also lamented that Khama was a wealthy man with a huge stake in the country's prime tourism region of the Okavango Delta, but does not bring Bangwato on board for economic empowerment. He claimed that Khama's business partners were white Europeans and Americans, while his subjects, Bangwato, only enjoy his charitable events. The author adds: 'Khama has never invited Bangwato to a meeting at the Serowe showground to talk about HIV/AIDS, poverty, crime, gender-based violence, unemployment and related social problems'. As far as the author was concerned, 'Sections of the tribe that want to join his campaign are committing a huge strategic blunder because they don't know whose interests it is really serving. If Botswana catches fire, they will forever be associated with arson started by someone who was never part of them' (Sunday Standard 20 May 2019). Perhaps, it was deliberate for the anti-Khama Sunday Standard not to have a by-line to the article. It is one of the private newspapers that had suffered greatly during Ian Khama's presidency, with its editor, Outsa Mokone, arrested and charged with sedition and a senior journalist, Edgar Tsimane, fleeing the country for South 
Africa. During Khama's crusade against Masisi, Tsimane published a piece in the Sunday Standard's sister publication, The Telegraph, with the title 'Charge Seditious Ian Khama' (Tsimane 14 August 2019). Khama is deculturalised from the African way of life even though he is a chief. He might not be a tribalist, but his approach in the 2019 general elections had the hallmarks of tribalism. In fact, even President Masisi's remarks during his campaigns also had some tribalistic connotations. This is not peculiar to Khama, Masisi, or Botswana political leaders, but ubiquitous in Africa (Opondo 2014).

The second school of thought was propounded by Professor Monageng Mogalakwe, who branded Khama 'a shameless tribalist' (Mogalakwe 14 October 2019). He argues that Botswana's 2019 general elections were different from all previous peaceful ones since independence. 'It appears that this time around, the African curse, also known as tribalism, is rearing its ugly head on Botswana's usually tranquil political landscape', notes Mogalakwe (14 October 2019). As far as Mogalakwe, who defined tribalism and made reference to the Rwandan genocide, is concerned:

The curse is being driven by none other than Ian Khama, the son of Botswana's celebrated first president, Seretse Khama [...] It is this 'glory' that his son now wants to bask in whilst pushing this nation towards a precipice. In this forthcoming elections Ian Khama, who has served the mandatory two terms of 5 years each as President, appears to want to come back through the back door, and we see him now fanning the ambers of tribalism in order to push out his successor, who is not a Khama. Tribalism [...] is a form of communal chauvinism that relies on primordial sentiment and appeals to the humanity's head instinct of communal solidarity. It always leads to 'us' and 'them' mentality and the exaltation of the 'us' group above the 'them' group.

This 'othering' of people has at times led to very tragic consequences, the likes of which we have seen in the Rwandan genocide. Tribalism, which is a vestige of ancient political communities, is also based on chiefly authority, or a belief in mythical hereditary divine right of precedence. Thus, Ian Khama, latter day Kgosi Kgolo of Bangwato, is going around the Central District [...] denouncing President Masisi, and hoping to exploit both the Bamangwato tribal sentiment and his chiefly authority to the detriment of the BDP and to his reincarnation under whatever guise. It is 
common knowledge across the length and breadth of Botswana that a Kgosi will call his people to a Kgotla, not a freedom square, to exchange views and receive feedback. What Ian Khama is doing is unprecedented in the annals of Botswana's customary law and practice. It is interesting to note that while this saga is unfolding, journalists who have been reporting on it, whether print or electronic media, have not called Ian Khama's political escapades by their real name: Tribalism, pure and simple. They have instead sugar-coated this despicable and naked tribalism by focusing on Ian Khama's status as paramount chief.

To my mind, Ian Khama is a shameless tribal chauvinist who is seeking to unleash a people's primordial and basic instinct, and to present his fight with Masisi, as in the interests of Bangwato or even BaMmagwato. Your readers will recall that not so long ago, Ian Khama stood in front of a crowd in Serowe and claimed that President Masisi wants to bury him, his family and the Bangwato. His words were: 'They want to bury me, my family and all of you'. This was a carefully crafted speech to appeal to and inflame Bangwato communal sentiment and those of other subject 'tribes' that together make up Bamangwato. This resort to communal chauvinism by Ian Khama for his own survival in his battle with President Masisi is really pathetic and desperate, to say the least (Mogalakwe 14 October 2019).

Mogalakwe did not spare Biggie Butale, saying 'it is also interesting to note that on the side of Ian Khama stands one Biggie Butale, a member of the Kalanga ethnic group or nationality [...] I would have thought this man would use his abundant energies to agitate for the cultural autonomy of the Kalanga people who have been facing cultural genocide for decades. But lo and behold, Biggie Butale, is fighting on the side of Ian Khama, as the socalled President of the BPF. To me this man has brought a new meaning to the expression "lap dog" (Mogalakwe 14 October 2019).

It is interesting what Mogalakwe says about Butale because this is precisely what Botswana politics is largely about- the pursuit of personal interest sometimes at all costs. Politicians are hardly driven by principles or policies. They shift or defect seamlessly from one faction to another within a party or across parties looking for greener pastures. Whereas some ordinary people on the ground may be moved by tribal sentiments peddled by some 
leaders or activists, the latter are largely not committed to such. For instance, a good number of defectors from the BDP or other parties to the BPF had lost primary elections and saw opportunities in the new party. It is not uncommon for the same people to defect back to their original parties for greener pastures. For instance, it did not take long for a large number of BDP members, who had left the party to form the BMD in 2010 to return to the BDP still under Khama, whom they had branded a despot. There were also reports of reverse migration from the BPF back to the BDP, while the Masisi-Khama feud intensified. In sub-Saharan Africa, politicians always appeal to tribal and ethnic sentiments to fight political battles. In Kenya and Burundi, for instance, ethnicity and tribalism often determine who wins elections, not manifestos (Cheeseman 2014; Daley 2006). African politicians should divorce tribal and ethnic issues from party politics. Tribalised politics lowers the quality of democracy and representation as voters tend to vote along tribal and ethnic lines.

\section{The South African Connection in the Campaign to 'Topple' Masisi}

The Botswana-South Africa ties predates the migrant labour from Botswana to the South African mines that started in the late nineteenth century. The Tswana-speakers in Botswana originate from South Africa where they number about five million, while in Botswana, they constitute a bigger portion of the country's two million inhabitants. Therefore, there are long historical and cultural ties between Botswana and South Africa. There is also a strong economic link between the two countries, with South Africa being Botswana's major trading partner. Since the colonial and apartheid periods, the landlocked Botswana has been economically dependent on the 'industrialised' South Africa for educational, professional, economic, and infrastructural facilities. For this reason, some people mistakenly think that Botswana is a province of South Africa.

In his 'battle' with Masisi, Khama sought support from some of his influential and moneyed Tswana-speaking associates in South Africa. In particular, he was alleged to have been assisted by the affluent Motsepe family, which includes the mining magnate, Patrice Motsepe, and his sister, Bridgette Motsepe-Radebe, who is married to a former Cabinet Minister in South Africa. During apartheid, Bridgette was exiled in Botswana, and she became a UB student among many South Africans. The Motsepes have established historical 
ties with members of the ruling elite in Botswana, which includes the Khamas and probably the Masisis (President Masisi's father was a veteran minister in both Seretse and Masire's cabinets). In the 1940s, Bridgette's father was at the same university as Seretse in South Africa. The Motsepes have a substantial stake or investment in various mining enterprises and other sectors in South Africa. They are also strongly connected to the summit of political power in South Africa where President Cyril Ramaphosa is married to a sister to Patrice and Bridgette. The media also alleged that by backing Khama, in his attempt to dislodge Masisi, the Motsepes were targeting Botswana's mineral wealth and the booming tourism sector. At some point, serious allegations appeared in the local private media claiming that the Motsepes had been intercepted by the Zimbabwean intelligence agents at the famed Victoria Falls, while attempting to fly millions of Pula in cash into Botswana. The money was said to have been earmarked to assist in the ill-fated Pelonomi Venson-Moitoi's campaign to 'oust' Masisi at Kang.

There was also an interception of mobile (phone) communication between Bridgette and Daphne Kadiwa, who was the Chief of Protocol in Khama's government, and his close confidant. Kadiwa was critical of Khama in her phone conversation with Bridgette, who strongly supported Khama and accused Masisi of being worse than the apartheid regime. These developments led to the Masisi government imposing a visa requirement on Bridgette, if she were to enter Botswana (Motlhoka 21-27 April 2019). The involvement or interference by members of the South African elite, who also belonged to the ruling African National Congress, in Botswana's internal politics, presented a diplomatic quandary for President Ramaphosa (Motlhoka 21-27 April 2019). A brother-in-law to Patrice and Bridgette, he was reported to have dispatched a high-level delegation, led by his minister of Foreign Affairs, to meet with President Masisi in Gaborone to mend fences.

Khama was also reported to have tried to solicit financial support for the BPF from his cousins, the Bafokeng royalty, who are quite wealthy from platinum mining in their territory in the North West Province of South Africa. It seems they were not prepared to interfere in Botswana internal politics and were reported to have rebuffed him (Sunday Standard 17 June 2019). The South African security authorities were also claimed to have declined to provide Khama with VIP escort after landing at Pilanesberg Airport on his way to Phokeng to meet with the Bafokeng royals. 
Khama's habit of using his South African connections for fund raising for his political cause and the South African media, even after the elections, whose results he dismissed as having been rigged, led to stern condemnation by some South Africans. They had become weary of his approach, particularly because, like other Africans, they had always held Botswana in high regard in terms of elections and democratic order. The South Africans were/are also faced with their own serious economic and social challenges in the form of elite corruption, high unemployment rate, violent crimes, gender-based violence, xenophobia, and regular and frequent electricity outages. True to form, Khama also spoke critically about some of these challenges, while in South Africa, instead of adopting a diplomatic approach. Not surprisingly, it was reported that 'Khama's Campaign in SA Attracts Scorn' as some South Africans took to the social media to lambast him (Thobega 18 December 2019). At the same time, Patrice Motsepe instituted a lawsuit against the Sunday Standard, which reported extensively about his alleged involvement in plots to oust Masisi.

\section{Conclusion}

This article has demonstrated that tribalism and ethnicity also feature a lot in Botswana's political landscape. This is not extraordinary as it happens across sub-Saharan Africa, but only differs in scale. Botswana is seen as 'a success story' and a 'politically stable' country in a gloomy continent; hence some of its social ills are glossed over by analysts. Nonetheless, tribalism and ethnicity in Botswana are unlikely to reach the level of Rwanda or Burundi where deadly ethnic conflicts often recur. Commentators urge the Botswana political leaders and all stakeholders to ensure that tribal and ethnic tolerance are entrenched and consolidated. Botswana's democratic culture seem to function well compared to many other countries in Africa, hence the Rwandan scenario is unlikely to obtain. The use of tribal and ethnic cards to attain political office in Botswana has not been successful, unless it involves a chief, as in the case of Ian Khama. He, however, failed to achieve his main objective of ousting Masisi, but only won three seats in his tribal fortress, Serowe. Credit should also be given to him for helping the UDC to win some seats in the Central District. Generally, voters are aware that the tribal card is counter-productive to the nation-building exercise. But sometimes tribal and ethnic loyalty seem 
to take precedence over national unity and cohesion. In almost every national election, political activists invariably try to play the tribal card.

However, in the case of Ian Khama, it seems he had banked on the fame his family name holds in the country, and a perception that the country is beholden to the Khamas, but like others exploiting tribal agenda in politics, his approach was not largely successful. This is despite having a family name that was/is a brand with a very long history and synonymous with political power and privilege in Botswana, as well as cross-border moneyed connections in South Africa. Although Khama failed to oust Masisi and the BDP, his party, the BPF, won three seats in his home village, Serowe. This shows that tribal loyalty, especially when a chief is involved in politics, can change the political landscape. The Serowe region had always been the stronghold of the BDP, since 1962.

The involvement of dikgosi in Botswana's partisan politics and elections was noted by the Southern African Development Community (SADC) election observers as a negative development for the country. The SADC advised against dikgosi's active participation in party politics and elections (SADC 2019). Progressive, as it is, this advice ignores the fact that since independence in 1966, Botswana's ruling political elite has drastically curtailed the chiefs' powers. Thus, the chiefs now know that attaining political office gives one real political and economic power. The ruling party, the BDP, has, over the years, enjoyed massive support from the chiefs. It appears that the problem arises when the chiefs resign from their hereditary position to join opposition ranks. This article does not argue that tribalism and ethnicity determined the outcome of the 2019 general elections. It only confines itself to the discourse of tribalism as it relates to the Khama-Masisi feud. Perhaps, a detailed study on how tribalism, and even regionalism, directly influenced the outcome of the 2019 elections is needed.

\section{References}

Acemoglu, D., S. Johnson \& J.A. Robinson. 2002. An African Success Story: Botswana. Available at: $\underline{\text { https: //ssrn.com/abstract }=304100}$

(Accessed on 21 November 2020.)

Adeyanju, C.G. 2020. Politics of Ethnicity in Nigeria: The Way Forward. Available at: 
https://www.foresightfordevelopment.org/featured/ethnicity-tribalism (Accessed on 20 November 2020.)

Ake, C. 1993. What Is the Problem of Ethnicity in Africa? Transformation 22:

1 - 14. Available at: http://transformationjournal.org.za/wpcontent/uploads/2017/03/tran022002.pdf

(Accessed on 17 November 2020.)

Albeely, T.S., A.T. Mahmoud \& A.I. Yahaya. 2018. Ethnicity, Tribalism, and Racism and Its Major Doctrines in Nigeria. Dirasat Ifriqiyya 59: 30 - 46. Available at:

http://dspace.iua.edu.sd/bitstream/123456789/3710/4/Ethnicity.pdf

(Accessed on 21 November 2020.)

Angstrom, J. 2000. The Sociology of Studies of Ethnic Conflict: Explaining the Causal Status of Development. Civil Wars 3,3: 23 - 44. Available at: https://www.tandfonline.com/doi/abs/10.1080/13698240008402445.

(Accessed on 21 November 2020.)

Berman, B.J. 2010. Ethnicity and Democracy in Africa. Available at: https://lawethiopia.com/images/ethnic\%20politics\%20in\%20ethiopia/Et hnicity\%20and\%20Democracy\%20in\%20Africa.pdf

(Accessed on 21 November 2020.)

Botlhale, P. 1998. Koma is to Blame. The Botswana Guardian 12 June.

Brown, C. 2020. Botswana Votes 2019: Two-Party Competition and the Khama Factor. Journal of Southern African Studies 46,4: 703 - 722. Available at:

https://www.tandfonline.com/doi/abs/10.1080/03057070.2020.1778901. (Accessed on 16 November 2020.)

Calhoun, C. 1993. Nationalism and Ethnicity. Annual Review of Sociology 19,1: 211 - 239. Available at:

https://is.muni.cz/el/1490/jaro2014/CZS13/um/2 Calhoun Nationalism. pdf. (Accessed on 16 November 2020.)

Carney, J.J. 2012. Beyond Tribalism: The Hutu-Tutsi Question and Catholic Rhetoric in Colonial Rwanda. Journal of Religion in Africa, 42,2: 172 202. Available at:

https://d1wqtxts1xzle7.cloudfront.net/34175833/Beyond_Tribalism_Catholic Rhetoric HutuTutsi_Question_in_Colonial_Rwanda_JRA_2012.pdf (Accessed on 20 November 2020.) 
Christian J. Makgala, Andy Chebanne, Boga T. Manatsha \& Leanoard S. Sesa

Cheeseman, N. 2008. The Kenyan Elections of 2007: An Introduction. Journal of Eastern African Studies 2,2: 166 - 184. Available at:

file:///C:/Users/MANATS 1/AppData/Local/Temp/TheKenyanElections of2007-AnIntroduction.pdf (Accessed on 16 November 2020.)

Club of Mozambique 2019. Khama Fomenting Divisions in Botswana -

Former Legislators. 15 May. Available at:

https://clubofmozambique.com/news/khama-fomenting-divisions-in-

botswana-former-legislators/

(Accessed on 29 November 2019.)

Concerned Motswana Citizen 2000. Concerned Motswana Citizen' Says

'Makalaka' Rule this Country. Mmegi Monitor 11 - 17 July.

Crowder, M. 1987. Tshekedi Khama, Smuts, and South West Africa. Journal of Modern African Studies 25,1: 25 - 42.

Daley, P. 2006. Ethnicity and Political Violence in Africa: The Challenge to the Burundi State. Political Geography 25,6: 657 - 679. Available at: https://pdfs.semanticscholar.org/3b99/7d20fbf2b64bb5f0cc1a8c60f65 ec8bba9c5.pdf

(Accessed on 21 November 2020.)

Delavignette, R. 1977. Robert Delavignette on the French Colonial Empire:

Selected Writings. Chicago: The University of Chicago Press.

Dingake, K. 2011. Unearthing the Hidden Treasure: The Untold Story of Gobe

Matenge. Gaborone: Medi Publishing.

Dingake, M. 1987. My Fight Against Apartheid. London: Kliptown.

Gabathuse, R. 2019. Khama Says 'Masisi Driving the Country to Rwanda'. Mmegi 1 March.

Gabathuse, R. 2019. Khama, GammaNgwato Tribal Politics. Mmegi 10 May.

Good, K. 2010. The Presidency of General Ian Khama: The Militarisation of the Botswana 'Miracle'. African Affairs 109: 315 - 324.

Grant, S. 1984. The Revival of 'Bogwera' in the Kgatleng: Tswana Culture or Rampant Tribalism? A Description of the 1982 'Bogwera'. Botswana Notes \& Records 16: 7 - 17. Available at:

https://journals.co.za/docserver/fulltext/botnotes/16/1/738.pdf?expires $=1$ 607044495\&id=id\&accname $=$ guest $\&$ checksum $=$ FFB32C0DB91F72AD

1BF34C2C3E127A7F (Accessed on 29 November 2019.)

Gulbrandsen, O. 2012. The State and the Social: State Formation in Botswana and Its Pre-colonial and Colonial Genealogies. New York and Oxford: Berghahn Books. 
Hale, H.E. 2004. Explaining Ethnicity. Comparative Political Studies 37,4: 458 - 485. Available at:

https://is.muni.cz/el/1423/podzim2016/POL401/um/Hale.pdf

(Accessed on 22 November 2020.)

Hamer, S. 2016. 'Our Father's Programmes': Political Branding around Social Protection in Botswana, 2008 - 2014. CSSR Working Paper No. 370. Centre for Social Science Research, University of Cape Town. Available at:

https://open.uct.ac.za/bitstream/handle/11427/21588/Hamer_Working\% 20Paper\%20370_2016.pdf?isAllowed=y\&sequence $=1$

(Accessed on 29 November 2019.)

Hermans, T. 1993. Lady Khama. Motswana Woman September.

Hettne, B. 1993. Ethnicity and Development: An Elusive Relationship. Contemporary South Asia 2,2: 123 - 149.

Ipotseng, K. 1998. BNF: Adopt Law of Contradiction. Mmegi 6 - 12 March.

Jackson, A. 1999. Tshekedi Khama, Bechuanaland, and the Central African Federation. South African Historical Journal 40,1: 202 - 222.

Kekeghe, S. 2020. Deculturalisation and Transculturalism in Sam Ukala's Iredi War. Available at:

https://www.researchgate.net/publication/342248186_Deculturalization and_Transculturalism_in_Sam_Ukala's_Iredi_War

(Accessed on 22 November 2020.)

Lekoa, C.K. 2019. Botswana and the Multilateral Foreign Policy. Botswana Notes and Records 51: 118 - 122. Available at:

file:///C:/Users/MANATS 1/AppData/Local/Temp/1730-

Article\%20Text-5070-1-10-20200122.pdf

(Accessed on 29 November 2019.)

Lentz, C. 1995. 'Tribalism' and Ethnicity in Africa: A Review of Four Decades of Anglophone Research. Cah. Sci. Hum. 31,2: 303 - 328.

Available at:

https://horizon.documentation.ird.fr/exldoc/pleins textes/pleins textes 4/sci hum/42875.pdf (Accessed on 22 November 2020.)

Mafeje, A. 1971. The Ideology of 'Tribalism'. The Journal of Modern African Studies 9,2: 253 - 261.

Magang, D. 2015. Delusions of Grandeur: Paradoxes and Ambivalences in Botswana's Macroeconomic Firmament. Gaborone: Print Media Consult. 
Christian J. Makgala, Andy Chebanne, Boga T. Manatsha \& Leanoard S. Sesa

Makgala, C.J \& M.Z. Botlhomilwe. 2017. Elite Interests and Political Participation in Botswana, 1966 - 2014. Journal of Contemporary African Studies 35,1: 54 - 72.

Makgala, C.J. \& I. Malila. 2014. The 2011 BOFEPUSU Strike: A Fight for Restoration of Workers Purchasing Power. Cape Town: Centre for Advanced Study of African Society.

Makgala, C.J. 2002. A Note on the History of Serowe. Botswana Notes and Records 34: 160 - 163. Available at:

https://journals.co.za/docserver/fulltext/botnotes/34/1/101.pdf?expires $=1$ 607046237\&id=id\&accname=guest\&checksum $=E 2 F 1137810 \mathrm{~A} 8 \mathrm{~A} 6 \mathrm{~A} 41$

3FF21419A07D67B (Accessed on 29 November 2019.)

Makgala, C.J. 2008. Historical and Politico-Cultural Significance of Botswana's Pula Currency. Pula: Botswana Journal of African Studies 22: 49 - 53.

Makgala, C.J. 2019. The Manifesto Experiment in the Internal Electioneering of the Botswana Democratic Party. Journal of African Elections 18,2: 134-157. Available at: https://www.eisa.org/pdf/JAE18.2.pdf\#page=139 (Accessed on 12 January 2020.)

Makgala, C.J., A. Chebanne \& M.M.M. Bolaane. n.d. 'Mind Your Language': Tribal Bigotry and the Spectre of Rwandan Genocide in Botswana, 20002002. (Paper in preparation).

Masire, Q.K.J. 2006. Very Brave or Very Foolish: Memoirs of an Africa Democrat. Gaborone: Macmillan.

Masokola, A. 2019. Masisi Blames Khama for the BDP Decline. Weekend Post 2 - 8 March.

Mogalakwe, M. \& F. Nyamnjoh. 2017. Botswana at 50: Democratic Deficit, Elite Corruption and Poverty in the Midst of Plenty. Journal of Contemporary African Studies 35,1: 1 - 14. Available at:

https://www.tandfonline.com/doi/pdf/10.1080/02589001.2017.1286636 (Accessed on 12 January 2020.)

Mogalakwe, M. 2019. Ian Khama: A Shameless Tribalist and His Kalanga Lapdog. Sunday Standard 14 October.

Molomo, M.G. 2000. Democracy Under Siege: The Presidency and Executive Powers in Botswana. Pula: Botswana Journal of African Studies 14,1: 95 $-108$.

Morima, N.A. 2015. The Pushback Against Moitoi is Motivated by Sexism. Weekend Post 15 January. 
Motlhabani, J.S. 2013. Why I Didn't Kiss Tatiana: 21 Days in the Big Brother Africa House. Gaborone: Author.

Motlhoka, T. 2019. Bridget Motsepe Faces Possible Ban from Entering Botswana. Sunday Standard 21 - 27 April.

Motlhoka, T. 2019. Ramaphosa Extends an Olive Branch to Botswana. Sunday Standard 21 - 27 April.

Motlogelwa, T. \& M. Civilini 2015. The Khamas - The Making of Military Millionaires. Business Weekly and Review 14 November.

Mulimbi, B. 2017. Botho - 'I Am Because We Are'. Constructing National Identity in the Midst of Ethnic Diversity in Botswana's Junior Secondary

Schools. PhD Dissertation: Harvard Graduate School of Education.

Nasha, M.N. 2014. Madam Speaker, Sir: Breaking the Glass Ceiling, One Woman's Struggles. Gaborone: Diamond Educational Publishers.

Nasong'o, W.S. 2015. The Roots of Ethnic Conflict in Africa: From Grievance to Violence. Houndmills: Palgrave Macmillan.

Nyati-Ramahobo, L. 2002. Ethnic Identity and Nationhood in Botswana. In Mazonde, I. (ed.): Minorities in the Millennium: Perspectives from Botswana. Gaborone: Lentswe La Lesedi.

Opondo, P.A. 2014. Ethnic Politics and Post-election Violence of 2007/8 in Kenya. African Journal of History and Culture 6,4: 59 - 67. Available at: https://academicjournals.org/article/article1398870139_Opondo.pdf

(Accessed on 20 November 2020.)

Parsons, N., W. Henderson \& T. Tlou. 1995. Seretse Khama, 1921 - 1980.

Gaborone: The Botswana Society and Macmillan.

Raditlhokwa, L. 1998. Koma Cannot Solve BNF Crisis. Mmegi 1 - 7 May. Raditlhokwa, L. 1998. Koma Should Step Down. Midweek Sun 28 January.

Ramatiti, K. 2019. Bangwaketse Tribesmen Distance Themselves from SKI, BPF. Weekend Post 8 July.

SADC. 2019. Preliminary Statement by Honourable Lt. Gen. Sibusiso Moyo [...] Head of the SADC Electoral Observer Mission (SEOM) to the 2019 Elections in the Republic of Botswana. Available at:

https://www.sadc.int/files/9715/7225/2549/Botswana SEOM Prelimina ry_Statement.pdf (Accessed on 29 January 2020.)

Samatar, A.I. 1999. An African Miracle: State and Class Leadership and Colonial Legacy in Botswana Development. Portsmouth: Heineman Press. 
Christian J. Makgala, Andy Chebanne, Boga T. Manatsha \& Leanoard S. Sesa

Schapera, I. 1938. A Handbook of Tswana Law and Custom. Oxford: Oxford University Press.

Schapera, I. 1940. The Political Organisation of the Ngwato of Bechuanaland Protectorate. In Fortes, M. \& E.E. Evans-Pritchard (eds.): African Political Systems. London: Oxford University Press.

Spring, J. 2010. Deculturalisation and the Struggle for Equality: A Brief

History of the Education of Dominated Cultures in the United States. New York: McGraw Hill.

Sunday Standard 2019. Bangwato Capital Gave Birth to a Provincial Party. 22 - 28 December.

Sunday Standard 2019. Khama too Culturally Western to be Tribalistic. 20 May.

Sunday Standard 2019. South Africa Pulls the Red Carpet from Khama's Feet. 17 June.

The Patriot 2019. Politics Divide Bogosi in Serowe. 20 October.

Thobega, K. 2019. Khama Backlash: Khama's Campaign in SA Attracts Scorn.

The Midweek Sun 18 December.

Tsimane, E. 2019. Charge Seditious Ian Khama. The Telegraph 14 August.

Venkatasawmy, R. 2015. Ethnic Conflict in Africa: A Short Critical

Discussion. Transcience 6,2: 26 - 37. Available at: https://www2.huberlin.de/transcience/Vol6_No2_26_37.pdf

(Accessed on 18 November 2020.)

Werbner, R. 2002. Cosmopolitan Ethnicity, Entrepreneurship and the Nation:

Minority Elites in Botswana. Journal of Southern African Studies: Special Issue on Minorities and Citizenship in Botswana 28,4: 731 - 753.

Werbner, R. 2004. Reasonable Radicals and Citizenship in Botswana: The

Public Anthropology of Kalanga Elites. Bloomington: Indiana University Press.

Andy Chebanne (PhD)

Professor of Linguistics 
The Discourse of Tribalism in Botswana's 2019 General Elections

Department of French

University of Botswana CHEBANNE@UB.AC.BW

Boga Thura Manatsha (PhD)

Senior Lecturer, History

Department of History

University of Botswana

ManatshaB@UB.AC.BW

Leonard L. Sesa (MA)

Lecturer, Political Science

Department of Political Science and Administrative Studies

University of Botswana 1sesa@UB.AC.BW 